\title{
AUTHOR/TITLE INDEX TO VOLUME 1 (1981/1982)
}

Barron, J.L.: see Dubois, C.P.R.

\section{Bearman, T. Carbo, U.S. information policy issues}

Blair, J.C., Jr., Transfer of technology: computer equipment selection and staff training protocols (computerized retrieval systems)

Blair, J.C., Jr., Training techniques for chemical searching online: considerations in designing a course in continuing education

Blair, J.C., Jr., ELITE - Electronic Library Information Transfer Experimentation (special issue prologue)

$187-189$

Book Reviews

Borrell, J., Computer graphics: an overview

Brooks, K.: see Parks, L.W.

Burnam, J.K., Users' needs for re-packaging and re-use of information

$359-366$

Calendar of Events

Conference Reports

Cullen, B.C., European trends in communications

Dubois, C.P.R. and Barron, J.L., Full word processor / mainframe integration: an information management application in a multi-task environment

Elias, A.W., International marketing aspects for information services

$87-94$

Elias, A.W., Pricing strategies and impacts on producers, vendors and users

Emard, J.P., Trends in biomedical telecommunications, information utilities and videotex

Grünsteidl, W., Man and automation in the office

263-270

Huleatt, R.S., Creating an information awareness

Hunter, J.A., Quantifiable characteristics of bibliographic databases

$331-340$

Kent, A.K., The information industry in the year 2000

$31-43$

Krasny, M.A., Technology - the problems and solutions

Lawrence, R.: see Parks, L.W.

Ljungberg, S., Euronet DIANE - pros and cons: some observations by an outsider

Matsumura, T., Some recent developments in information activities in Japan

Mignon, E., Telecommunications and the research library, a partisan overview

Oppenheim, C., Technology and the information professional: will it make a difference?

Parks, L.W., Brooks, K., and Lawrence, R., An instructional experiment in usage of online information retrieval systems by entry-level and end-users 
Questions and Answers

Rankine, L.J., The socio-economic consequences and limits of the information revolution

$65-73$

Rosenberg, V., Cultural and political traditions and their impact on the transfer and use of scientific information

Smith, T.E., Computerized data bases

$215-218$

Tabohashi, A., Report on the Science Information Centre in Japan

279-289

Underwood, M.J., The present situation regarding vocal data acquisition

$57-64$

Vaillancourt, P.M., Use of the BIOSIS computerized data base taught with adiovisual technology

$81-86$

Whitehead, J.B., Communications using word processing systems

$109-138$

Wilde, D.U., The re-use and re-packaging of bibliographic information: issues and problems (Introduction)

$329-330$

Yamakawa, T., The current online situation in Japan

$147-150$ 